\title{
A quantitative assessment of rockfall influence on forest structure in the Swiss Alps
}

\author{
Christine Moos $^{1}\left[\right.$ D $\cdot$ Nora Khelidj $^{2} \cdot$ Antoine Guisan $^{2,3} \cdot$ Heike Lischke $^{4} \cdot$ Christophe F. Randin $^{1,2,5}$
}

Received: 14 July 2020 / Revised: 14 July 2020 / Accepted: 7 September 2020 / Published online: 18 September 2020

(c) The Author(s) 2020

\begin{abstract}
Forests below rocky cliffs often play a very important role in protecting settlements against rockfall. The structure and development of these forests are expected to be substantially affected by the disturbance of the falling rocks. Knowing about this effect is important to predict the development of protection forests and consider potential effects of the falling blocks in management strategies. The goal of this study is to quantify differences in forest structure depending on rockfall activity in four different sites in the Swiss Alps. For this, we collected data on forest structure in zones of different rockfall activity and derived rockfall impact probabilities based on rockfall simulations. We assessed whether differences in forest structure and signs of rockfall disturbance could be observed between the rockfall zones. We additionally built mixed-effects models to identify the key variables explaining the forest characteristics described by diameter (DBH) and basal area (bA). The forest structure differs between the rockfall zones, however, with varying effects amongst the sites. DBH tends to decrease with increasing rockfall activity, whereas tree density appears to be little impacted by rockfall. For most sites, the number of deposited blocks and the simulated tree impact probability have a significant effect in the models along with the species, whereas for one site, hardly any effect of rockfall was found. Our results, obtained either from direct measurements or modelling, show that rockfall can locally influence the structure of forests, whereas the influence depends on the frequency and intensity of the rockfall disturbance. Impact probabilities obtained by simulations can serve as a good proxy for rockfall disturbances.
\end{abstract}

Keywords Rockfall $\cdot$ Forest structure $\cdot$ Disturbance $\cdot$ Protection forest $\cdot$ Rockfall impact probability

\section{Introduction}

Rockfall is one of the most frequent and widespread natural hazards in mountain regions and can pose a severe threat to infrastructure and human life. Besides technical protective measures, such as nets or dams, protection forests play a very important role as natural means of protection against rockfall. Trees can stop or deviate falling blocks and reduce their energy (Dupire et al. 2016). They have been recognized as one of the most sustainable and cost-effective measure (Accastello et al. 2019; Berger et al. 2013; Moos et al. 2019a). In Switzerland, $43 \%$ of the total forested area have a protective function and $8 \%$ of them protect against rockfall (Losey and Wehrli 2013).

Forests do not only protect against rockfall, but the rockfall process itself can influence the structure and development of the forest. Falling blocks can harm or even break standing trees, as impact marks and uprooted trees in forests located below a rockfall source indicate (Aydin et al. 2012).

5 Centre Alpien de Phytogéographie, Champex-Lac, Switzerland 
There is an increasing number of studies that have assessed the protective effect of forests against rockfall (e.g. Dorren et al. 2005; Dupire et al. 2016; Maringer et al. 2016; Moos et al. 2017; Stoffel et al. 2006). In contrast, the effect of rockfall on forest structure and development has been less studied (e.g. Aydin et al. 2012; Perret et al. 2006). Single falling blocks can create small openings by killing single trees, while larger events, such as rock avalanches, destroy entire parts of the forest and create large gaps. These gaps provide light and space promoting natural regeneration of the forest, similarly as done artificially in forest management (Dorren et al. 2004). Consequently, younger forest stands are expected in zones of high rockfall activity, where trees die frequently. In zones with less frequent impacts, the growth and thus the diameter of the remaining trees could be increased resulting in fewer, but thicker trees.

In case a tree is not killed, but only damaged by a block, this might still have long-lasting effects on its growth and survival. Pests and diseases are more likely to affect the tree through the scars and can cause tree death after a couple of years (Stoffel and Hitz 2008; Woltjer et al. 2008). The degree to which a tree is harmed by a block depends on its size, its impact velocity, the position of the impact, the diameter of the impacted tree and the tree species (Dorren and Berger 2006). In general, conifers are more susceptible to rock impacts than broadleaved trees (Moos et al. 2019b; Stokes et al. 2005; Vospernik 2004). Toe et al. (2017), however, found tree species to be of minor importance for the reduction in the block energy.

Knowing about the effect of rockfall on the forest is important to accurately predict the development of a rockfall protection forest and consider potential effects of the falling blocks in forest management strategies. In forest stand models, for example, rockfall has rarely been taken into account as disturbing agent (Woltjer et al. 2008). This could lead to a significant bias in the prediction of forest development at local scale in steep and complex terrain as found in mountain regions.

In this study, we aimed at filling these knowledge gaps, by comparing the differences in forest structure as a function of tree density, tree diameter and tree species in different rockfall activity zones. We further calculated and analysed rockfall impact probabilities on trees based on rockfall simulations. We focused on four rockfall sites in the Swiss Alps with single falling blocks as dominant rockfall process and where large rock slides or rockfall are rare (decennial to centennial) events. Here we hypothesized that:

- tree diameters and tree density both decrease with increasing rockfall activity

- rockfall can locally influence the distribution and composition of tree species

\section{Material and methods}

We collected and analysed data on forest structure from four different rockfall sites in the Swiss Western Alps (Fig. 1 and Table 1) and derived rockfall impact probabilities on single trees based on rockfall simulations.

\section{Study sites}

Chillon. The study site of Chillon is located in the Canton of Vaud, at the north-east side of the Lake of Geneva at the foothills of the Alps. This site ranges between 370 and $800 \mathrm{~m}$ a.s.1. The slope varies from $20^{\circ}$ to $80^{\circ}\left(20^{\circ}\right.$ and $50^{\circ}$ in the forested area). More than 14 tree species were recorded in sample plots, of which the most abun dant are Fagus sylvatica, Taxus baccata and Tilia platyphyllos.

Nax. The study site of Nax is located in the canton of Valais, close to the city of Sion at an elevation between 579 and $1215 \mathrm{~m}$ a.s.l. The region is known for rockfall events and the studied forests protect a road from falling blocks. The slope increases from $25^{\circ}$ to $80^{\circ}\left(45^{\circ}\right.$ in the forested area). The forest is mainly composed of Pinus sylvestris and Betula Pendula with increasing abundance of Quercus pubescens. There has been hardly any forest intervention in the past 30 years, except for the removing of single dry Pine trees (information from local forest manager and orthophotos).

Martigny. The study site is also in the canton of Valais. The altitude varies between 510 and $800 \mathrm{~m}$ a.s.l., and the slope has an inclination between $0^{\circ}$ and $70^{\circ}\left(0^{\circ}\right.$ and $55^{\circ}$ in the forested area). The forest is situated right above the city, and several rockfall events have happened in the region. The forest is mainly composed of Fagus sylvatica, Pinus sylvestris, Abies alba and Picea abies. In the past 30 years, the forest has been intervened several times, where relatively large openings for regeneration were created (information from local forest manager and orthophotos).

Täsch. The study site of Täsch is located in the Matter Valley (canton of Valais). Its elevational range lies between 1400 and $3200 \mathrm{~m}$ a.s.l. with forest reaching an elevation of 2000-2100 $\mathrm{m}$ a.s.l. It is known to be a high intensity rockfall zone (Stoffel et al. 2005). In addition, other natural hazard processes, such as snow avalanches and debris flow, take frequently place. The slope inclination increases from $\sim 20^{\circ}$ at the bottom to $84^{\circ}$ in the release area $\left(50^{\circ}\right.$ in the forested area). The forest is dominated by Larix decidua, followed by Picea abies and some occurrences of Pinus sylvestris. Between 2006 and 2016, a couple of moderate forest interventions removing single trees (a total of $\sim 1000$ $\mathrm{m}^{3}$ in an area of $\sim 3000 \mathrm{~m}^{2}$ in 10 years) have been conducted (information from local forest manager and orthophotos). 

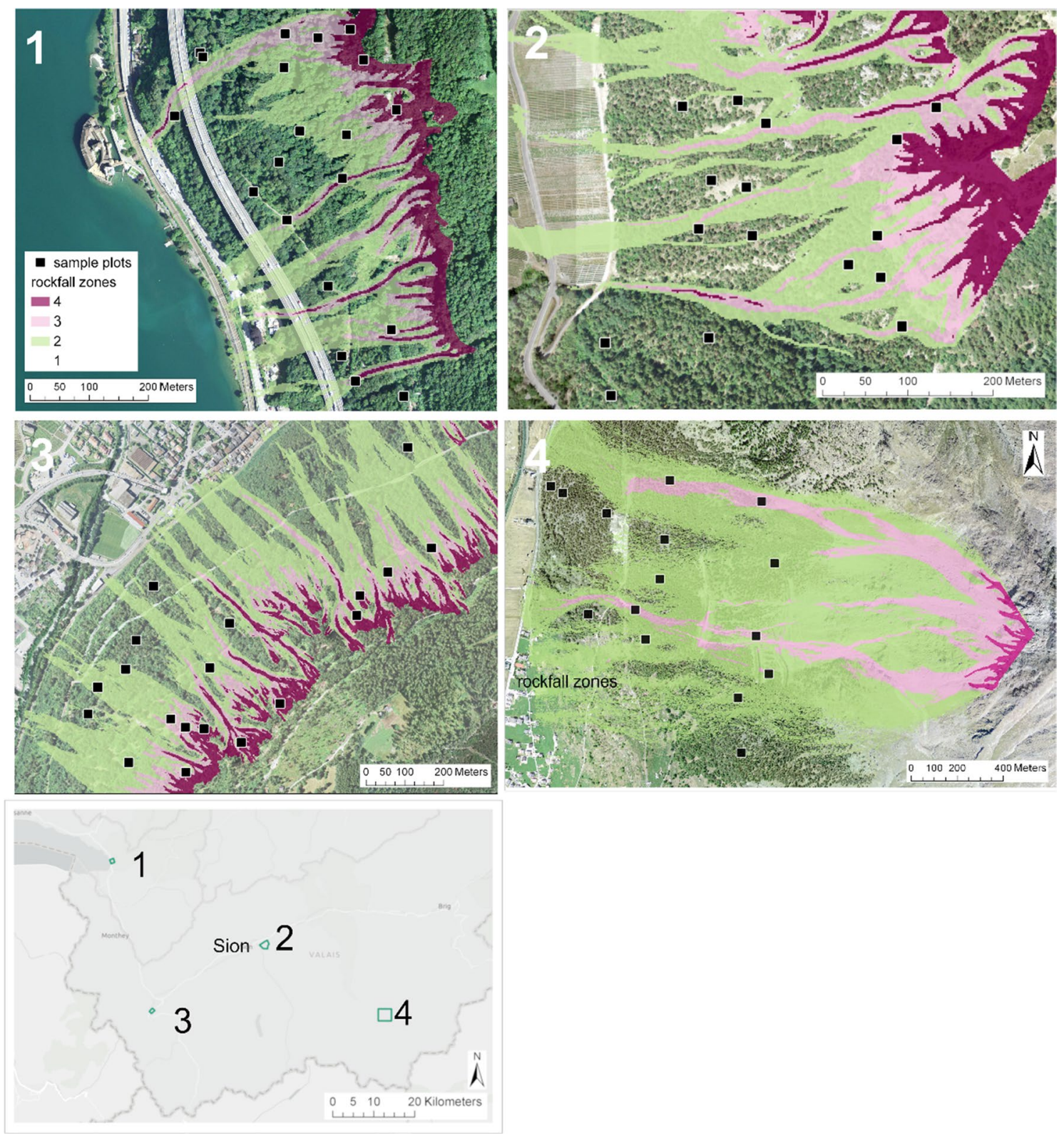

Täsch. (Color figure online)

\section{Data collection in the field}

At each site, we measured forest structural characteristics in sample plots stratified by different "rockfall zones" (Fig. 1). Rockfall zones were determined based on rockfall simulations with the three-dimensional model RockyFor $3 D$ (Dorren 2016; see also chapter 2.3). The simulations were conducted for the unforested slope and a block volume of $2 \mathrm{~m}^{3}$, and the "reach probability" of the blocks was then classified into four rockfall zones. The reach probability of a specific cell is the probability that it is reached by a block given that it has detached from the release area. It is calculated as the percentage of simulated blocks reaching the cell and normalized with the number of source cells feeding the cell. We classified the rockfall activity in areas with a reach probability of $<2 \%$ as "low", for a reach probability between 2 and $5 \%$ as "medium", between 5 and $10 \%$ as "high" and $>10 \%$ as "very high". In each of the four rockfall zones (with 4 being the most active rockfall zone), we defined five sampling sites in the field. The samples were randomly distributed in the respective zone aiming at an even distribution over the slope. In Täsch, no sample was taken in zone 4 since this zone is not forested and in Nax, only one sample was taken in zone 4 , since 
Table 1 Rockfall and forest characteristics of the four case study sites. The onset frequency corresponds to the estimated average number of blocks per year of the considered block volume range releasing from the cliff

\begin{tabular}{|c|c|c|c|c|c|c|}
\hline Site & $\begin{array}{l}\text { Forested } \\
\text { area [ha] }\end{array}$ & Geology & $\begin{array}{l}\text { Size rock- } \\
\text { fall release } \\
\text { area [ha] }\end{array}$ & Block volume range & $\begin{array}{l}\text { Estimated onset frequency } \\
\text { for total release area }\left(F_{\text {onset }}\right)\end{array}$ & Dominant species \\
\hline Chillon & 21.3 & Limestone & $\sim 3.3$ & $0.01-5 \mathrm{~m}^{3}$ & $15 \mathrm{yr}^{-1}$ & $\begin{array}{r}\text { Tilia sp., Fagus sylvatica, Taxus } \\
\text { bachata / Acer pseudeplatanus }\end{array}$ \\
\hline Martigny & 77.1 & Gneiss and mica slate & $\begin{array}{l}\sim 2 \text { (small, } \\
\text { dis- } \\
\text { persed } \\
\text { rock } \\
\text { cliffs) }\end{array}$ & $0.01-5 \mathrm{~m}^{3}$ & $30 \mathrm{yr}^{-1}$ & $\begin{array}{l}\text { Fagus sylvatica, Abies alba, } \\
\text { Pinus sylvestris }\end{array}$ \\
\hline Nax & 45.2 & Dolomite & $\sim 4$ & $0.01-5 \mathrm{~m}^{3}$ & $21 \mathrm{yr}^{-1}$ & Pinus sylvestris, Betula pendula \\
\hline Täsch & 151.8 & Gneiss & $\sim 17$ & $0.05-20 \mathrm{~m}^{3}$ & $103 \mathrm{yr}^{-1}$ & Larix decidua, Picea abies \\
\hline
\end{tabular}

most of the zone is already part of the release area and thus hardly accessible or unforested.

At each sampling site, we measured the diameter at breast height (DBH) and the species of each tree in a $20 \times 20 \mathrm{~m}$ plot (measured on the slope). We determined the "main species classes" (species proportion $>2 \%$ ) at each site and classified the rest as "deciduous" or "conifers". In addition, the following site characteristics were recorded:

- The number of freshly deposited blocks larger than 0.05 $\mathrm{m}^{3}$. We considered blocks with few signs of weathering (limited patina, absence of blunt edges) and the absence of lichens or vegetation on the surface as fresh estimating the age of their deposition being less than $100 \mathrm{yrs}$.

- The number of trees (NrT)

- The basal area (bA) calculated from the DBH and the number of trees per hectare

- Rockfall damages on trees (fresh $(<1 \mathrm{yr})$, old ( $>1 \mathrm{yr})$, no damage)

Since differences between the sample plots could strongly be influenced by the management history of the forest, we determined for each sample plot whether it has been influenced by forest interventions in the past $\sim 30$ years (yes / no) based on orthophotos, information from local forest managers and signs in the field (i.e. logged stems and tree stumps). We only considered information that could be clearly distinguished from other disturbances (such as rockfall).

\section{Simulated tree impact probabilities}

Based on data on tree density, species and diameter distribution from the sample plots, we created positions of single trees, which we used in the rockfall simulations. We determined forest areas that are homogenous regarding tree density, tree height and species-based orthophotos and calculated then the tree density and the mean tree diameter and the standard deviation per species using the data from the sample plots taken in the respective homogenous area. Random trees were finally generated in each area based on the derived tree density and diameter distribution. We conducted rockfall simulations with the rockfall module RockyFor $3 D$ for different block volumes and the generated single trees. RockyFor $3 D$ is a "probabilistic process-based" rockfall model that simulates flying, bouncing and rolling blocks in three dimensions depending on the terrain as well as standing trees. The latter are considered spatially explicitly and after each impact of a block on a tree, the energy reduction in the block is calculated depending on the tree species, the tree diameter and the impact position (Dorren 2016). We determined the rockfall release area based on orthophotos and slope inclination and mapped soil type and soil roughness in homogenous areas in the field following Dorren (2016). The simulations were conducted with a digital elevation model with a resolution of $2 \mathrm{~m}$. The considered block volume distribution was fitted using a power law distribution (e.g. Dussauge-Peisser et al. 2002; Hantz et al. 2003) based on measurements of block deposits in the field for Täsch and Nax. For Chillon and Martigny, we fitted the power law distribution based on literature values (e.g. Hantz et al. 2016; Moos et al. 2018) and validated it with field samples of deposited blocks and inventory data of passed rockfall events registered by the cantonal authorities. We classified the block volumes in eight classes and simulated each class 100 times per start cell with uniformly sampling the block volume from the respective class (total number of simulations between 75,000 and 1,100,000). The deposited blocks measured on the slope and the inventory data served also to validate the simulated rockfall runout zones.

We registered for each tree the number of rock impacts. In case the impact energy of the block is higher than the energy that can be dissipated by the tree, it is registered as "fatal impact". We then calculated the "conditional impact probability" (hereafter designated as $P_{\text {imp }}$ ) as the proportion of the number of tree hits per tree on the total number of simulated blocks per single tree and derived rasters of 
the mean and the maximum impact probability, respectively, with a spatial resolution of $20 \mathrm{~m}$. The $P_{\text {imp }}$ is the probability that a tree is hit given that a block (of the considered block volume range) has released from the cliff. We further calculated the frequency of trees being actually impacted $\left(F_{\text {imp }}\right)$ as the product of the yearly rockfall onset frequency $\left(F_{\text {onset, }}\right)$ of the respective block volume $\mathrm{i}$, the considered time period $\left(N_{\text {yrs }}\right.$; here $\left.10 \mathrm{yrs}\right)$ and $\mathrm{P}_{\text {imp }}$ and then summed up over all considered block volumes V (Eq. 1).

$F_{\text {imp }}=\sum_{i=1}^{V} F_{\text {onset }, i} \times N_{\text {yrs }} \times P_{\text {imp }, i}$

The onset frequency per block volume $\mathrm{V}_{\mathrm{i}}\left(F_{\text {onset, } \mathrm{i}}\right)$ was calculated as the product of the average yearly onset frequency $A$ of volumes $\mathrm{V}$ larger than the minimum volume $\mathrm{V}_{0}$ and the relative frequency of block volume $V_{i}$ (e.g. Dussauge-Peisser et al. 2002; Eq. 2).

$F_{\text {onset }, i}=A \times{\frac{V_{i}}{V_{0}}}^{-b}$

The parameter $b$ was derived from the fitted power law distribution of the block volumes and literature values, respectively. In the case of Täsch, $A$ was estimated based on available data from dendrogeomorphological analyses and rockfall deposits assessed in previous studies (Moos et al. 2018; Stoffel et al. 2005). For the other study sites, we estimated $A$ based on tree damages below the release area. We counted all visible tree damages classified as "fresh" (younger than approximately 1 year) in a strip of $10 \mathrm{~m}$ width $20 \mathrm{~m}$ below the cliff, following Trappmann and Stoffel (2013). We then calculated $A$ based on the "conditional impact probability" (CIP) concept (Moya et al. 2010). We considered minimum block volumes between 0.01 and $0.05 \mathrm{~m}^{3}$ (depending on the site). It can be assumed that also smaller block volumes $\left(\sim 0.001 \mathrm{~m}^{3}\right)$ can cause damages on trees, which rarely kill them. However, these damages can still increase the tree mortality due to a higher vulnerability to pest and diseases. We partially took this into account by considering $P_{\text {imp }}$ (conditional probability that a tree is impacted by a block) and not $P_{\text {kill }}$ (conditional probability that a tree is killed by a block). However, $P_{\text {kill }}$ might still be slightly underestimated.

\section{Statistical analysis}

Our statistical analyses are divided into two main parts: based on field observations, we first assessed whether differences in forest structural parameters as well as signs of rockfall disturbance could be observed between rockfall zones within the four study sites. We then built multivariate models to identify the key variables (i) among disturbances by rock, (ii) topography and (iii) tree species composition explaining best the forest characteristics (i.e. DBH and bA).

\section{Differences in forest characteristics}

Based on the data from the field samples, we tested whether there were significant differences in the diameter distribution, the tree density, the basal area (bA) and the species distribution between the different rockfall zones using ANOVA, a Kruskal-Wallis test and a chi-square test for frequency data (tree number, species). We further analysed differences in the proportion of damaged trees and their diameters, the impact probability on trees $\left(P_{\text {imp }}\right)$ and the probability of trees being killed $\left(P_{\text {kill }}\right)$ as well as the number of deposited blocks in the sample plots.

\section{Multivariate models explaining forest characteristics}

We then analysed the DBH of individual trees and the bA per plot $\left(\mathrm{bA}_{\mathrm{plot}}\right)$ as a function of rockfall, terrain and forest parameters using multivariate models. We designed hierarchical linear mixed-effects models (LMM) with the sample plot (in the case of DBH), the rockfall activity class and the site as random effects, which allowed us to account for random effects that might influence our target variables, but could not be integrated as fixed effects. They include local differences in stand age, soil characteristics or further effects of management and disturbance history not covered in this study. The LMM were implemented with the lmer function of the lme 4 package in the statistical software $\mathrm{R}$ (Bates et al. 2015). We first fitted them for each site with the sample plots and the rockfall class as random effects and then over all data with the sites as additional random effect. We used the slope, the elevation above sea level, the number of deposited blocks, the probability of trees being impacted $\left(P_{\text {imp }}\right)$, the categorical variable for management (managed / unmanaged in the past 30 years) and the species as potential explanatory variables in the LMM (fixed effects). We calculated the Spearman correlation coefficient between the variables and considered only variables that are not substantially correlated to avoid colinearity (spearman correlation coefficient $<0.4$ ). We tested each variable separately and defined the final model based on stepwise backward variable selection aiming at reducing the Akaike Information Criterion (AIC) using the step function (lmerTest package; Kuznetsova et al. 2017) for LMM. We also tested for potential interactions between the predictor variables. The models were examined based on customary residual plots (Stahel 2017) and variables transformed to their natural logarithm if indicated. $P$ values for the LMM were obtained by WaldChisq tests as well as likelihood ratio tests of the full model against the model without the variable in question ("Appendix"). The $\mathrm{R}^{2}$ of the fixed effects in the LMM was calculated 
as the marginal and the conditional $\mathrm{R}^{2}$ based on Nakagawa and Schielzeth (2012).

\section{Results}

\section{Signs of rockfall activity}

At all sites, there are clear signs of trees being more impacted by rockfall in zones of higher rockfall activity. There are significantly more damaged trees in the rockfall zones 3 and 4 with a higher proportion of freshly damaged trees (Fig. 2). Additionally, the number of deposited blocks increases with increasing rockfall activity with significantly more blocks in zones 3 and 4 for all sites expect for Martigny, where most blocks were recorded in zone 1 (Fig. 3).

The mean and maximum conditional impact probabilities $\left(P_{\text {imp }}\right)$ as well as the calculated probability of a tree being actually hit in $10 \mathrm{yrs}\left(F_{\mathrm{imp}}\right)$ significantly increase in zone 3 and 4 at all sites (Fig. 4). Furthermore, $F_{\text {imp }}$ is higher for damaged trees compared to undamaged trees with significant

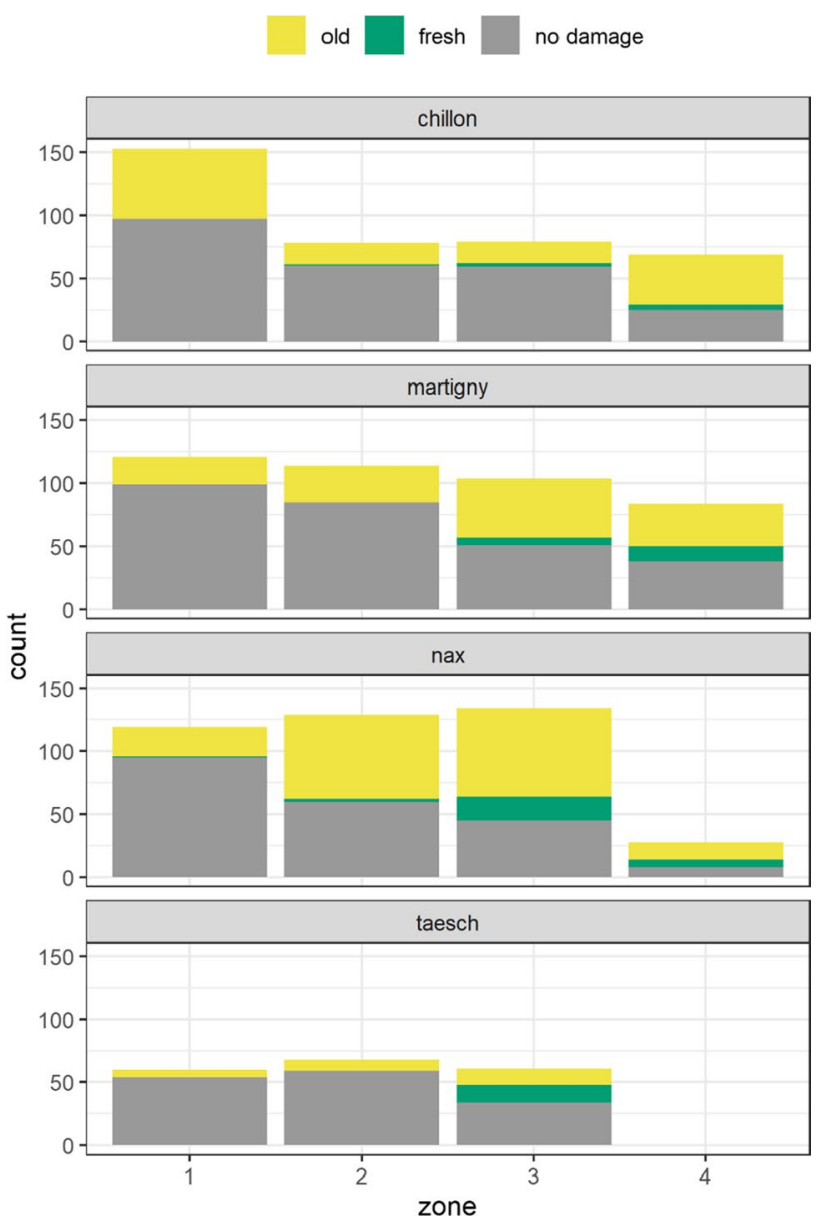

Fig. 2 Number of trees per rockfall zone and site with no (grey), old (yellow) and fresh (green) damages. (Color figure online)

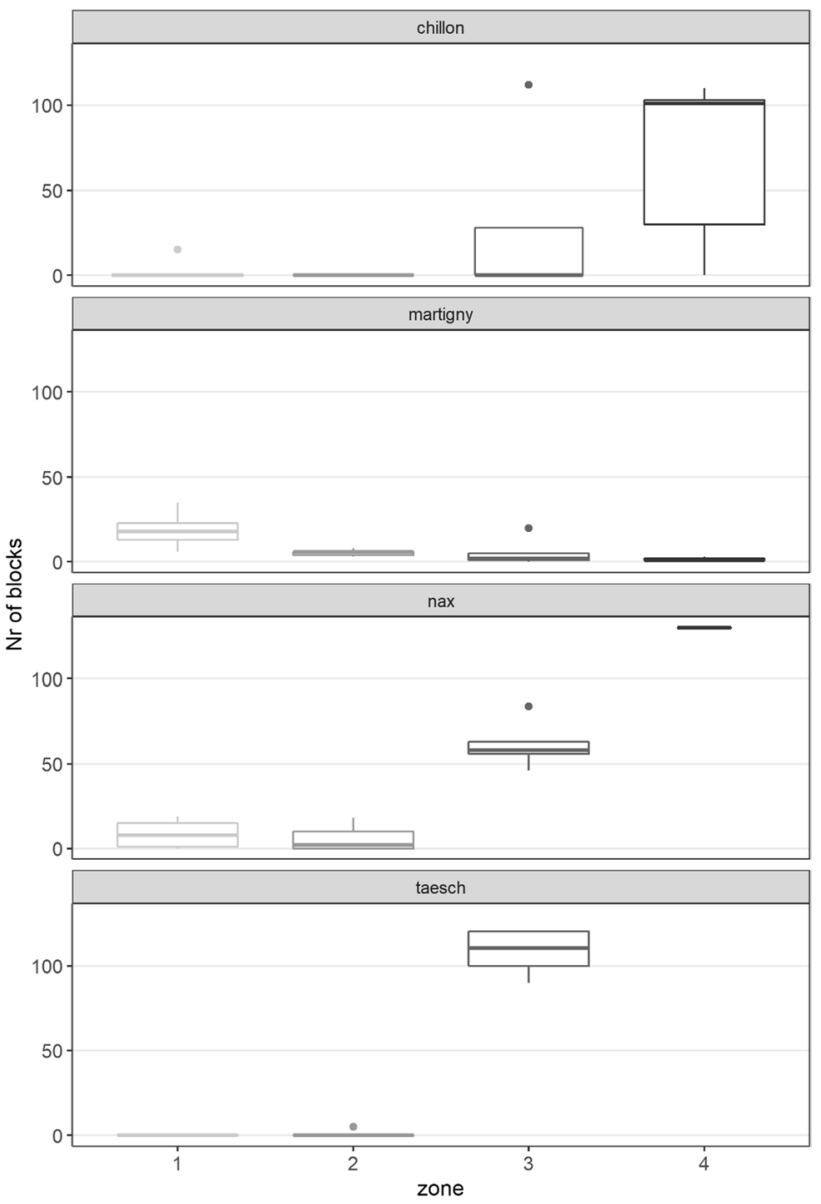

Fig. 3 Distribution of number of deposited blocks per sample plot per rockfall zone and site

differences for Nax, Martigny and Chillon (Fig. 5). $P_{\text {imp }}$ reaches highest values in Chillon (median $P_{\text {imp }}$ in zone $4=6.4 * 10^{-4}$ ) and $F_{\text {imp }}$ is highest in Täsch (median $F_{\text {imp }}$ in zone $3=0.06$ ) and Chillon (median $F_{\text {imp }}$ in zone $4=0.09$ ), whereas $P_{\text {imp }}$ and $F_{\text {imp }}$ are substantially lower at Nax and Martigny. In addition, the mean slope in the sample plots is significantly higher in zone 4 (Martigny, Chillon) and zone 3 (Täsch, Nax), respectively, compared to zone 1 and 2 (not shown).

\section{Differences in forest characteristics}

The forest structure clearly differs between the rockfall zones, however, with strongly varying effects between sites. In Täsch, DBH significantly decreases with increasing rockfall activity (Fig. 6 and Fig. 9 in "Appendix"), and bA is significantly lower in rockfall zone 3 , but there is no major difference in tree density between the rockfall zones (Table 2). In Chillon, DBH is significantly lower in the rockfall zone 3 compared to rockfall zone 1 and 2, whereas it increases again in rockfall zone 4 . No significant differences in bA 

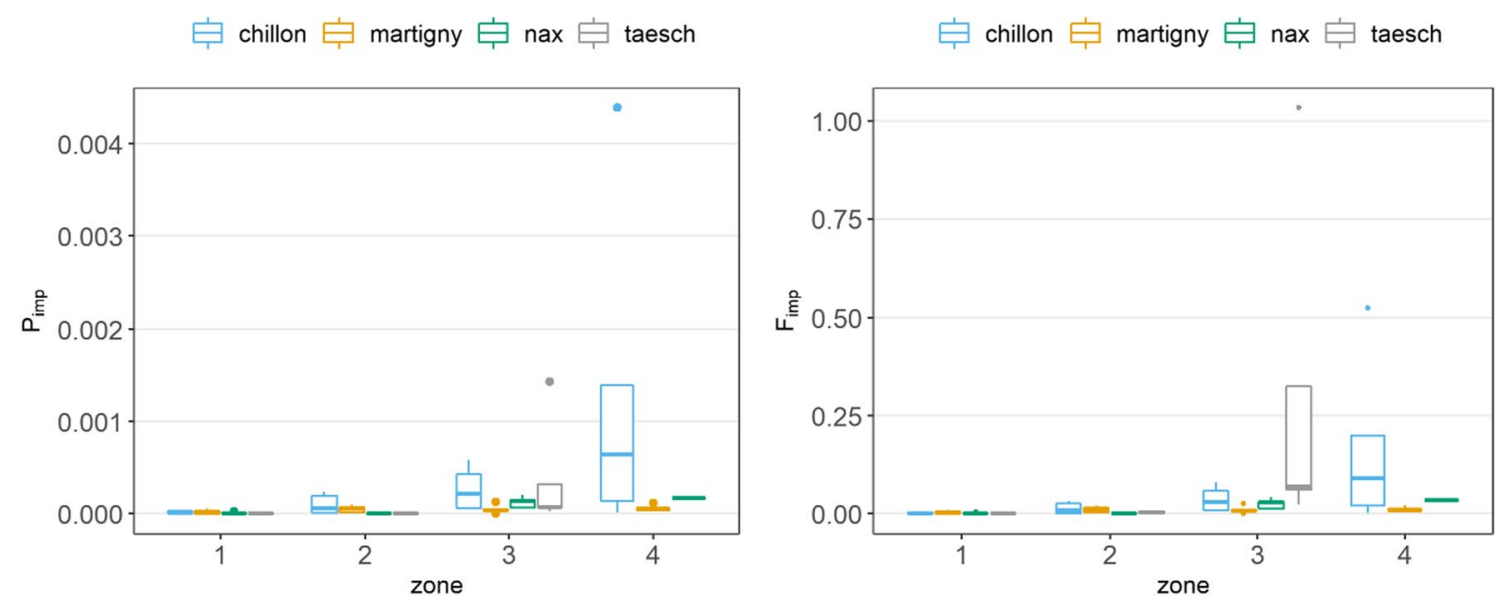

Fig. 4 Distribution of calculated conditional impact probabilities on trees $\left(P_{\text {imp }}\right.$; left $)$ and calculated mean probabilities of a single tree of being actually hit (in a time period of $10 \mathrm{yrs})\left(F_{\mathrm{imp}}\right.$; right) in the four rockfall zones and for the four sites

Fig. 5 Distribution of calculated probabilities of a single tree of being actually hit (in a time period of $10 \mathrm{yrs})\left(F_{\mathrm{imp}}\right)$ for damaged and undamaged trees at the four sites (different scales for $y$-axis)
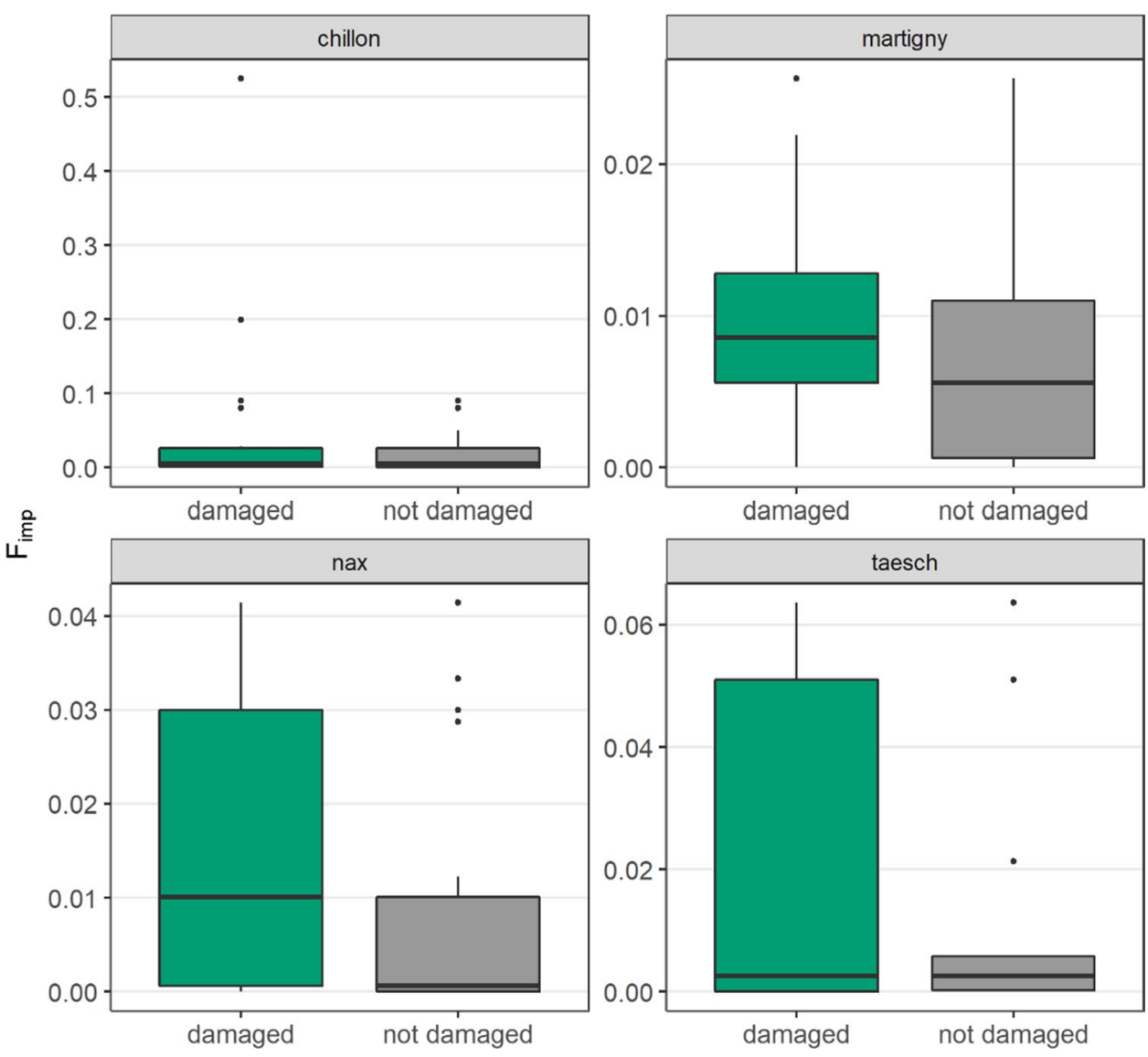

nor tree density could be observed. In Martigny, a slight increase in DBH and bA can be observed from zone 1 to zone 4 with significantly larger DBH and basal area in zone 4 compared to zone 1 . This effect is especially pronounced for Acer and Tilia. Tree density does not substantially differ between zones. In Nax, the DBH is largest in zone 2 and significantly lower in zone 4 compared to zone 1 and 2 .
Tree density as well as bA slightly increases with increasing rockfall activity, whereas the difference is not significant. In Chillon, Nax and Martigny, trees with rockfall damages have a significantly higher DBH compared to undamaged trees, whereas no significant difference was found for Täsch (not shown). Furthermore, the species proportion does not differ between rockfall zones in Täsch (Table 2). Rockfall zone 


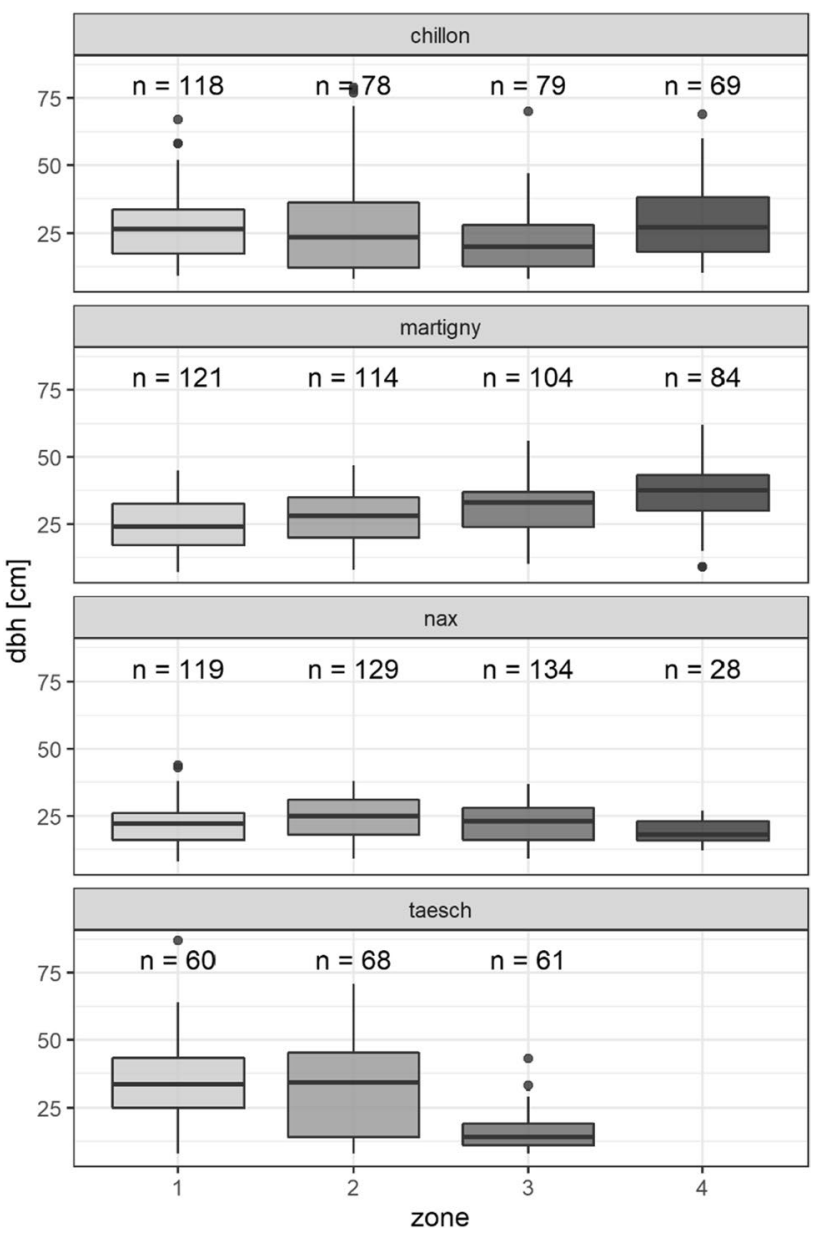

Fig. 6 Distribution of DBH per rockfall zone (4=highest rockfall activity) for the four sites

4 in Chillon has a higher proportion of Tilia and Fagus. In Martigny, there is an increasing proportion of Larix, Abies and Picea and a decreasing proportion of Fagus and Pinus in zones of higher rockfall activity. In Nax, there is a distinctly higher proportion of Pinus and Betula in rockfall zone 4.

\section{Multivariate models predicting forest characteristics}

In Täsch, the number of deposited blocks (Nr_blocks) and the impact probability $\left(P_{\text {imp }}\right)$ significantly influence DBH together with the tree species (Spp_class), whereas both factors are highly correlated (Nr_blocks remains in the final LMM for DBH and $P_{\text {imp }}$ in the final LMM for $\mathrm{bA}_{\text {plot }}$ ) (Table 3, Figs. 7 and 8). No significant effect is found for the mean slope (Slope) nor the elevation (Elevation). $\mathrm{Nr}_{-}$ blocks also significantly influences DBH and $\mathrm{bA}_{\text {plot }}$ in Nax together with Slope and Elevation, but is only significant in interaction with Spp_class in the LMM. In Martigny, the final LMM for DBH contains Elevation and Spp_class and for $\mathrm{bA}_{\text {plot }}$ additionally Management as significant variables, while Slope and $N r \_b l o c k s$ are also significant if regarded separately. In contrast to the other sites, $N r \_$blocks and $P_{i m p}$ are negatively correlated. No significant effects of $P_{i m p}$, Slope and Elevation are revealed in the models for DBH in Chillon, where the interaction of $N r_{-}$blocks with $s p p \_c l a s s$ is significant and the interaction of Nr_blocks and Slope, respectively, with spp_class for $\mathrm{bA}_{\mathrm{Plot}}$. The performance of the final LMM in terms of $\mathrm{R}^{2}$ ranges between 0.17 (marginal $\mathrm{R}^{2}$, Chillon) and 0.38 (marginal $\mathrm{R}^{2}$, Taesch) for $\mathrm{DBH}$ and 0.46 (marginal $\mathrm{R}^{2}$, Chillon) and 0.80 (marginal $\mathrm{R}^{2}, \mathrm{Nax}$ ) for $\mathrm{bA}_{\text {Plot }}$ (Table 3). In the LMM for all sites, Nr_blocks, spp_class and Slope are significant for $\mathrm{DBH}$ and $\mathrm{bA}_{\text {plot }}$. The models have a marginal $R^{2}$ of 0.25 and 0.46 , respectively (Table 3, "Appendix").

\section{Discussion}

Our assessment of four different rockfall protection forests in the western Swiss Alps shows that rockfall can influence the structure of forests below cliffs. However, effects of rockfall are not equally expressed and differ among sites. While DBH tends generally to decrease with increasing rockfall activity (Täsch, Nax, Chillon), significantly higher DBH can be observed in the zone of the highest rockfall activity at two sites (Chillon, Martigny). A possible reason for this is that regeneration is impeded in these highly active rockfall zones and only large trees above a certain size persist, which must have rejuvenated in a rockfall-free period. Similarly, Perret et al. (2006) observed low stem densities, large diameters and almost no regeneration close to the release area in a rockfall forest in the Swiss Alps where they recorded and analysed rockfall damages on trees. Besides the regular impacts of falling blocks, the soils in zones of high rockfall activity consisting of unstable debris are likely to hamper tree growth (Leitgeb et al. 2013) with potential negative effects on the water holding capacity at the soil surface. In Täsch, trees are even completely suppressed in the zone with the highest rockfall activity, where other disturbances, such as snow avalanches and debris flows, are also very frequent (Stoffel et al. 2005). It is the most active rockfall site, characterized by the highest rockfall release frequency and the largest block volumes. It is also the only site where we did not find larger diameters of damaged compared to undamaged trees, indicating that a higher proportion of the impacted trees actually dies. In addition, Täsch is the site located at the highest elevation, where low temperatures and short vegetation seasons further hamper tree growth. These factors are in line with the fact that rockfall activity, together with tree species composition, best explains DBH based on the multivariate models in Täsch when compared to the other sites.

Our field observations were overall in line with the simulated probabilities of a tree being hit by falling blocks. 
Table 2 Summary of the forest characteristics (mean DBH, tree density and mean bA and proportion of the three most frequent species) per site and rockfall zone

\begin{tabular}{|c|c|c|c|c|}
\hline \multicolumn{5}{|l|}{ Chillon } \\
\hline Rockfall zone & Mean DBH [cm] (standard dev.) & $\begin{array}{l}\text { Mean tree density }\left[\mathrm{ha}^{-1}\right] \text { (standard } \\
\text { dev.) }\end{array}$ & Mean bA $\left[\mathrm{m}^{2} \mathrm{ha}^{-1}\right]$ (standard dev.) & $\begin{array}{l}\text { Species proportion ( } 3 \\
\text { most frequent) }\end{array}$ \\
\hline 1 & $27(12)$ & $535(142)$ & $36(10)$ & $\begin{array}{l}22 \% \text { Fagus } \\
19 \% \text { Taxus } \\
17 \% \text { Acer }\end{array}$ \\
\hline 2 & $27(18)$ & $453(121)$ & $37(17.6)$ & $\begin{array}{l}35 \% \text { Tilia } \\
21 \% \text { Fagus } \\
13 \% \text { Acer }\end{array}$ \\
\hline 3 & $22(1)^{* 1,2,4}$ & $609(89)$ & $30(10.2)$ & $\begin{array}{l}27 \% \text { Tilia } \\
23 \% \text { Taxus } \\
13 \% \text { Acer }\end{array}$ \\
\hline 4 & $29(13)$ & $488(322)$ & $40(19.4)$ & $\begin{array}{l}\text { 34\% Tilia*1,3 } \\
\mathbf{2 9} \% \text { Fagus }^{* 1,2,3} \\
14 \% \text { Taxus }\end{array}$ \\
\hline \multicolumn{5}{|l|}{ Martigny } \\
\hline Rockfall zone & Mean DBH [cm] (standard dev.) & $\begin{array}{l}\text { Mean tree density }\left[\mathrm{ha}^{-1}\right] \text { (standard } \\
\text { dev.) }\end{array}$ & Mean bA $\left[\mathrm{m}^{2} \mathrm{ha}^{-1}\right]$ (standard dev.) & $\begin{array}{l}\text { Species proportion ( } 3 \\
\text { most frequent) }\end{array}$ \\
\hline 1 & $25(9)$ & $743(83)$ & $41(12)$ & $\begin{array}{l}47 \% \text { Pinus } \\
40 \% \text { Fagus } \\
6 \% \text { deciduous }\end{array}$ \\
\hline 2 & $28(10)$ & $711(80)$ & $48(13)$ & $\begin{array}{l}34 \% \text { Fagus } \\
25 \% \text { Pinus } \\
15 \% \text { Acer }\end{array}$ \\
\hline 3 & $31(10)$ & $638(94)$ & $52(3)$ & $\begin{array}{l}36 \% \text { Fagus } \\
24 \% \text { Pinus } \\
20 \% \text { Larix }\end{array}$ \\
\hline 4 & $36(12)^{* 1}$ & $719(106)$ & $82(14) * 1$ & $\begin{array}{l}\text { 33\% Larix*1,2 } \\
29 \% \text { Fagus }^{* 1} \\
14 \% \text { Abies }{ }^{* 1,2,3}\end{array}$ \\
\hline \multicolumn{5}{|l|}{ Nax } \\
\hline Rockfall zone & Mean DBH [cm] (standard dev.) & $\begin{array}{l}\text { Mean tree density }\left[\mathrm{ha}^{-1}\right] \text { (standard } \\
\text { dev.) }\end{array}$ & Mean bA $\left[\mathrm{m}^{2} \mathrm{ha}^{-1}\right]$ (standard dev.) & Species proportion \\
\hline 1 & $22(7)$ & $731(120)$ & $30(6)$ & $\begin{array}{l}\text { 41\% Pinus } \\
14 \% \text { Betula } \\
13 \% \text { deciduous }\end{array}$ \\
\hline 2 & $25(8)$ & $774(126)$ & $40(10)$ & $\begin{array}{l}55 \% \text { Pinus } \\
22 \% \text { Betula } \\
11 \% \text { Fagus / Populus }\end{array}$ \\
\hline 3 & $23(7)$ & $935(177)$ & $41(5)$ & $\begin{array}{l}54 \% \text { Pinus } \\
29 \% \text { Betula } \\
6 \% \text { Larix / Salix }\end{array}$ \\
\hline 4 & $19(4)^{* 1,2}$ & $1037(0)$ & $31(0)$ & $\begin{array}{l}\text { 61\% Pinus*1,2 } \\
\text { 36\% Betula*1,2 } \\
3 \% \text { deciduous }\end{array}$ \\
\hline \multicolumn{5}{|l|}{ Täsch } \\
\hline Rockfall zone & Mean DBH [cm] (standard dev.) & $\begin{array}{l}\text { Mean tree density }\left[\mathrm{ha}^{-1}\right] \text { (standard } \\
\text { dev.) }\end{array}$ & Mean bA $\left[\mathrm{m}^{2} \mathrm{ha}^{-1}\right]$ (standard dev.) & Species proportion \\
\hline 1 & 34 & $347(155)$ & $39(18)$ & $\begin{array}{l}\text { 88\% Larix } \\
8 \% \text { Picea } \\
3 \% \text { Pinus }\end{array}$ \\
\hline 2 & 33 & $371(249)$ & $40(14)$ & $\begin{array}{l}\text { 99\% Larix } \\
1 \% \text { Picea }\end{array}$ \\
\hline 3 & $16^{* 1,2}$ & $355(143)$ & $8(6)^{* 1,2}$ & $\begin{array}{l}\text { 93\% Larix } \\
7 \% \text { Picea }\end{array}$ \\
\hline 4 & 0 & 0 & 0 & No trees \\
\hline
\end{tabular}

*indicates that the value is significantly different from the respective other rockfall zone(s) (indicated with number) based on the ANOVA and chi-square test (for species proportion). 


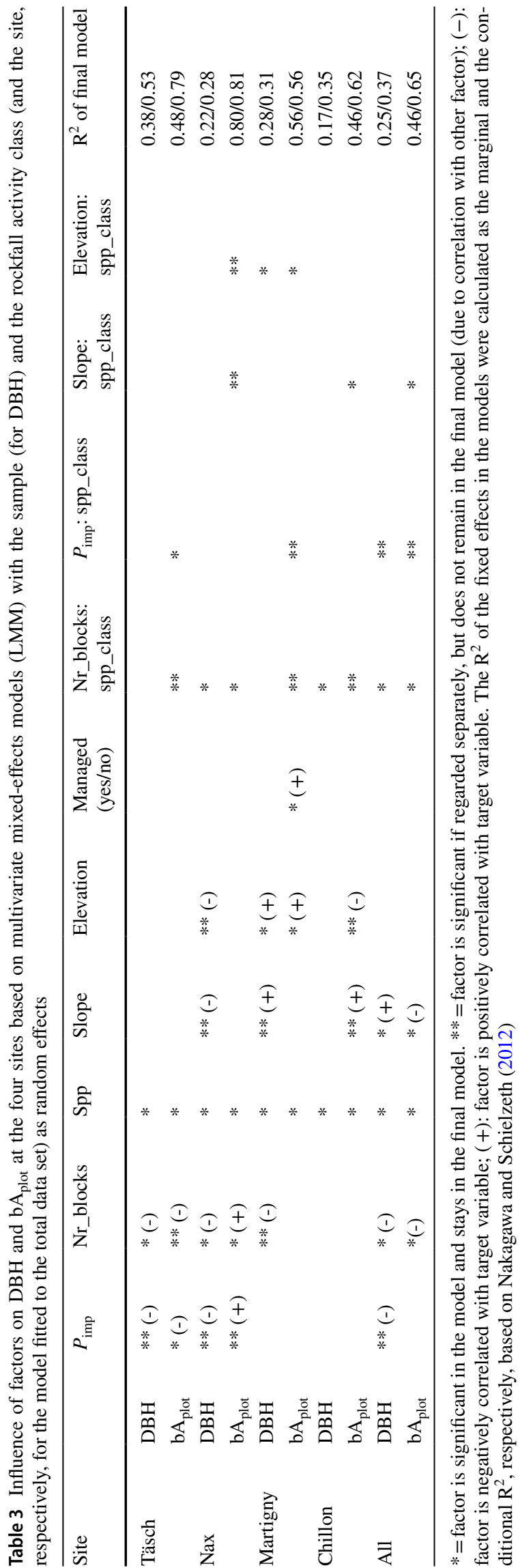

Where differences in forest structure between the rockfall classes are more pronounced (i.e. Täsch and Chillon), there is also a substantially larger increase in $\mathrm{F}_{\text {imp }}$. Conversely, $\mathrm{F}_{\text {imp }}$ is relatively low in all rockfall classes in Martigny, which can mostly be explained by the combination of a low tree impact probability and a relatively low rockfall release frequency. Indeed, tree impact probability is expected to be mainly influenced by the terrain, the slope length, the block volumes, the tree density and, to a minor degree, also the tree species (Moos et al. 2017). Despite the lower simulated probabilities of trees being killed for certain sites, we found clear evidence in terms of tree damages and deposited blocks that trees in higher rockfall zones are more impacted by blocks. In contrast to the other sites, where the number of deposited blocks in the field is positively correlated with the tree impact probabilities, the sample plots with the highest number of blocks in Martigny did not have the highest impact probabilities. Possible reasons are decreasing impact probabilities in the deposition area, where rocks decelerate and stop, as well as spatial variations in the onset frequency of rockfall that were not considered here. The high significance of the number of blocks in the multivariate models further indicates that not only the impact by blocks, but also the presence of debris, which locally alter the soil and hydric conditions, influences tree growth. In general, our results suggest that the simulated impact probability well correlates with the rockfall impact on trees in forests and could thus be used as proxy variable to further study the effect of rockfall disturbance on trees in dynamic forest landscape models, for example.

The results of our study indicate that the influence of rockfall on the distribution of species is limited. The tendency for higher abundance of Larix in zones of higher rockfall activity compared to Picea trees in Täsch is in line with the general expectation of Larix being a pioneer species that is accordingly more present in disturbed areas ( $\mathrm{Da}$ Ronch et al. 2016). In Martigny, conifers (Picea, Abies, Larix) are predominantly present in the most active rockfall zone with a decreasing abundance of Fagus and Pinus. This is, however, most likely an elevation and not a rockfall effect (increase in conifers with increasing elevation), as also evidenced by the significant effect of elevation in the mixed models. Vospernik (2004) found higher growth losses due to rockfall damage for broadleaf trees compared to spruce, but no influence of rockfall damage on fir, larch and pine based on the analysis of increment data from rockfall sites in Austria.

The mixed model for all sites shows a general influence of rockfall on forest structure. However, the correlation is not obvious for all sites, indicating that rockfall disturbance may be superimposed by other factors influencing the tree diameters. These other factors could be other natural disturbances, such as snow avalanches, wind, wild fires or browsing, as well as effects of forest management not covered 
Fig. 7 BHD of trees dependent on the number of deposited blocks (a), the tree impact probability $\left(P_{\text {imp }} ; \mathbf{b}\right)$, the mean slope (c) and the elevation a.s.l. (d) with linear regression per site. The axis of plot (a) and (b) are transformed to their logarithm

Fig. 8 Basal area per plot $\left(\mathrm{bA}_{\text {Plot }}\right)$ dependent on the number of deposited blocks (a), the tree impact probability $\left(P_{\text {imp }}\right.$; b) the mean slope (c), and the elevation a.s.l. (d) with linear regression per site. The axis of plot (a) and (b) is transformed to their logarithm
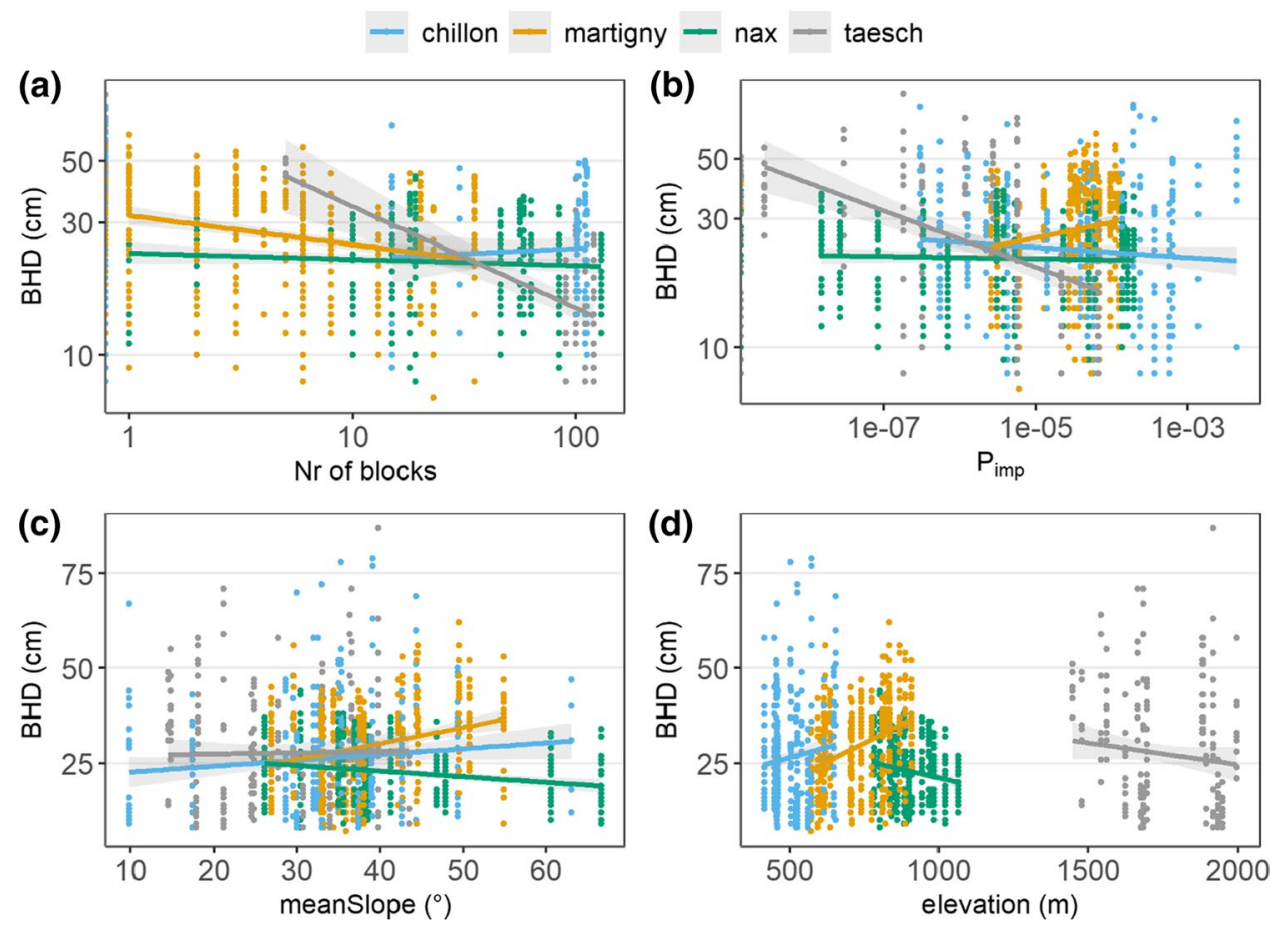
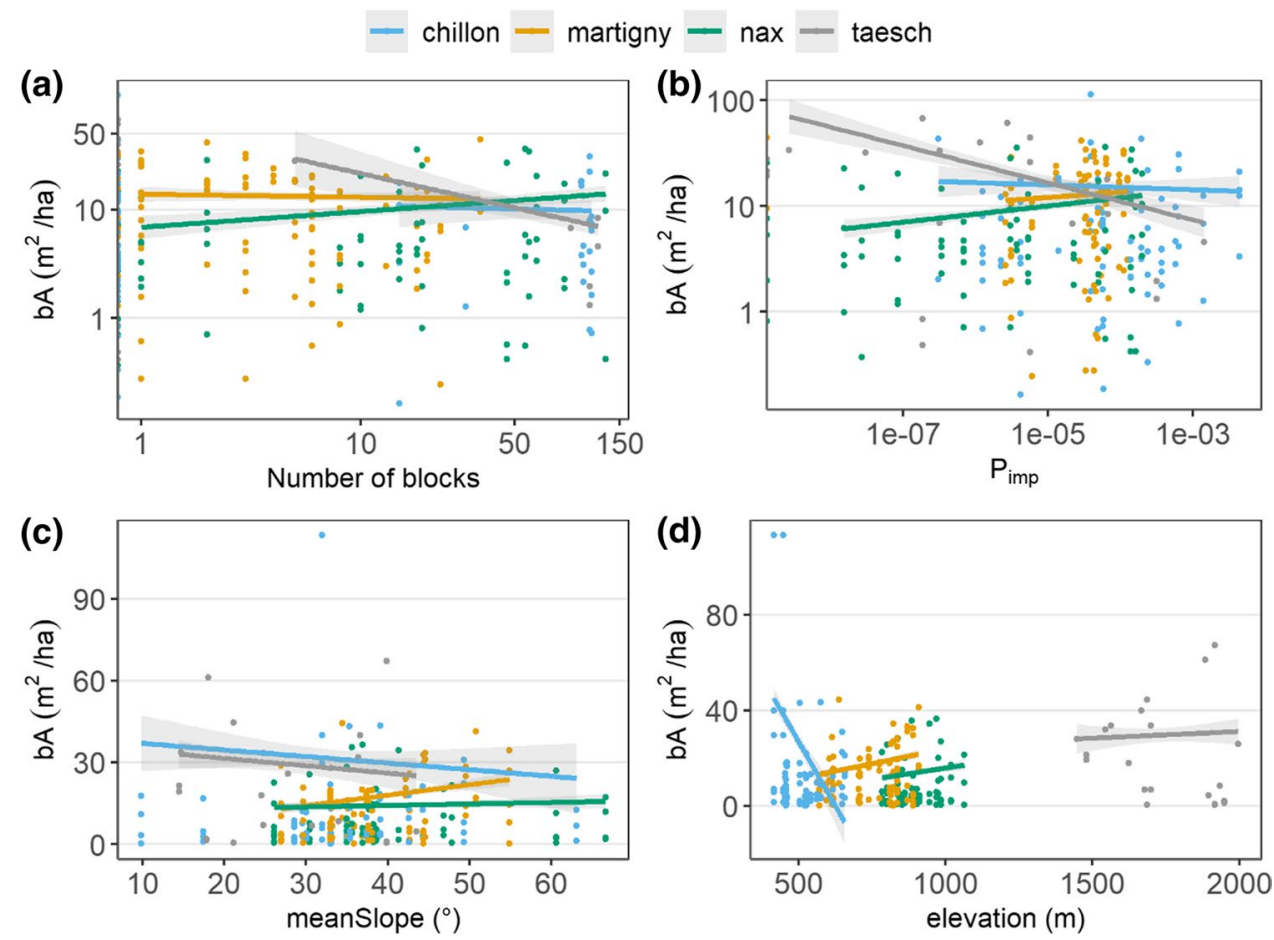

here (e.g. Maringer et al. 2016; Vacchiano et al. 2015). The forest in Martigny has been intervened frequently in the past 30 years, but also earlier in the last century (Farquet and Métral, 2004), whereas the other sites experienced less intensive or hardly any management. We therefore expect that differences in forest structure observed for Martigny are strongly influenced by the management history. In general, we expect less forest interventions in zones of high rockfall activity, since such areas are hard to access and working conditions there are difficult. Often, large diameter trees are envisaged to provide a high protection from rockfall (Dorren et al. 2004) and thus maybe have been favoured by foresters leading to higher diameters in the most active rockfall zone for certain sites. Furthermore, other factors influencing the 
micro-habitat of trees (e.g. local topo-climate or soil conditions) are likely to influence tree growth, but were not considered in this study.

Finally, the rockfall disturbance itself, at least not too frequent single block events, can have a positive effect on the forest, i.e. increase its stability and resistance. The falling blocks create small gaps where rejuvenation is fostered (Dorren et al. 2004). Thus, the question arises whether the regular creation of small gaps by rockfall would be sufficient to ensure the rejuvenation necessary for long-term stability and under which conditions rockfall it is too frequent to allow for rejuvenation. To answer this question, more data on regeneration and forest development depending on rockfall activity, which were not assessed in this study, would be necessary.

\section{Conclusions}

Our study provides new quantitative support to the influence of rockfall on forest structure for different forest types and rockfall slopes. We revealed a correlation between rockfall activity and forest structure indicating a disturbing effect of rockfall on the forest, but our results also show that this disturbing effect depends on the local conditions. Yet, differences in forest structure are likely further influenced by other important factors, such as other types of disturbances, pests and diseases, or soil and hydric conditions.

The frequency and potentially also the intensity of the rockfall disturbance that affect forest structure are in turn affected themselves by the forest: trees in the upper part of the slope can protect the trees below from rockfall impacts by stopping and decelerating falling blocks. Although the number of deposited blocks (as "empirical evidence" of rockfall disturbance) turned out to be the more robust factor in the statistical models, our results indicate that the simulated impact probability of rocks on trees can serve as a good proxy for the frequency of rockfall disturbance. Simulated rockfall disturbances could be thus coupled to dynamic forest models (see, for example, Woltjer et al. 2008) such as gap models (e.g. ForClim: Bugman 1996) or forest landscape models (e.g. TreeMig; Lischke et al. 2006). Such processbased models build upon explicit causal relationships representing key physiological, ecological and demographic processes (Dormann et al. 2012). With such coupling, twoway interactions between rockfall and forest structure could be studied in more detail with simulations under different scenarios, e.g. of rock release, climate change and forest management.
Funding Open access funding provided by University of Lausanne. The funding of this research was provided by the "Interdisciplinary Centre for Mountain Research" (CIRM) of the University of Lausanne as part of a postdoctoral project on the temporal evolution of the protective effect of forests against rockfall.

Availability of data and materials Data and material are available on request.

Code availability Code is available on request.

\section{Compliance with ethical standards}

Conflict of interest Not applicable.

Open Access This article is licensed under a Creative Commons Attribution 4.0 International License, which permits use, sharing, adaptation, distribution and reproduction in any medium or format, as long as you give appropriate credit to the original author(s) and the source, provide a link to the Creative Commons licence, and indicate if changes were made. The images or other third party material in this article are included in the article's Creative Commons licence, unless indicated otherwise in a credit line to the material. If material is not included in the article's Creative Commons licence and your intended use is not permitted by statutory regulation or exceeds the permitted use, you will need to obtain permission directly from the copyright holder. To view a copy of this licence, visit http://creativecommons.org/licenses/by/4.0/.

\section{Appendix}

\section{DBH Distribution per site and rockfall zone}

See Fig. 9

\section{Likelihood ratio test of linear mixed-effects models over all sites}

\section{BHD}

\section{Final model:}

$\log (\mathrm{DBH}) \sim$ Nr_blocks + spp_class + spp_class :

Nr_blocks + Slope + (1| site/zone/sample $)$

Model without interaction:

$\log (\mathrm{DBH}) \sim \mathrm{Nr}$ _blocks + spp_class

+ Slope $+(1 \mid$ site/zone/sample $)$

Base model (random effect only) (Table 4):

$\log (\mathrm{DBH}) \sim(1 \mid$ site/zone/sample $)$

\section{bA}

Final model: 
Fig. 9 Density of tree diameters (DBH) in the four rockfall zones (1-4) per site

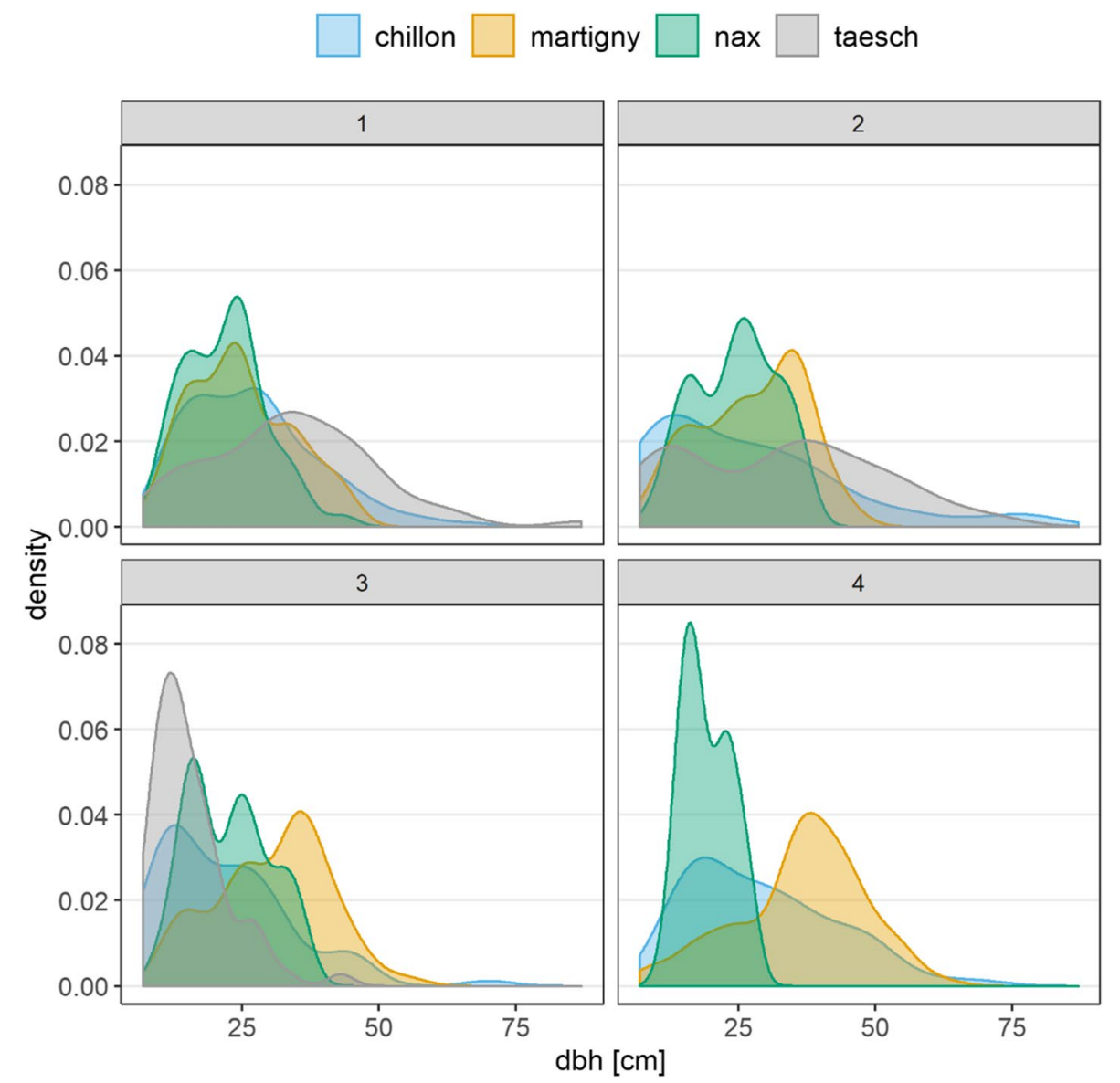

Table 4 Likelihood ratio test between models for dbh with degrees of freedom (Df) AIC, BIC, deviance and $P$ value

\begin{tabular}{llllll}
\hline Model & Df & AIC & BIC & Deviance & $P$ value ( $>$ Chisq) \\
\hline Base model & 5 & 1.609 .0 & 1636.2 & 1599.9 & \\
Model no int & 22 & 1491.5 & 1606.8 & 1447.5 & $<2.2 * 10-16$ \\
Final model & 36 & 1466.2 & 1655.0 & 1394.2 & $1.7 * 10-6$ \\
\hline
\end{tabular}

Table 5 Likelihood ratio test between models for bA with degrees of freedom (Df) AIC, BIC, deviance and $P$ value

\begin{tabular}{llllll}
\hline Model & Df & AIC & BIC & Deviance & $P$ value $(>$ Chisq) \\
\hline Base model & 4 & 4285.0 & 4307.1 & 4277.9 & \\
Model no int & 21 & 3434.3 & 3545.9 & 3392.3 & $<2.2 * 10-16$ \\
Final model & 49 & 3231.3 & 3491.6 & 3133.3 & $<2.2 * 10-16$ \\
\hline
\end{tabular}

Log $($ bA_ha $) \sim$ Nr_blocks + spp_class + spp_class : Nr_blocks

+ Slope + spp_class : Slope $+(1 \mid$ site/zone $)$

\section{Model without interaction:}

$\log ($ bA_ha $) \sim$ Nr_blocks + spp_class + Slope $+(1 \mid$ site $/$ zone $)$
Base model (random effect only) (Table 5):

$\log ($ bA_ha $) \sim(1 \mid$ site $/$ zone $)$

\section{References}

Accastello C, Bianchi E, Blanc S, Brun F (2019) ASFORESEE: a harmonized model for economic evaluation of forest protection against rockfall. Forests 10:578-594. https://doi.org/10.3390/ f10070578

Aydin A, Kose N, Akkemik U, Yurtseven H (2012) Assessment and analysis of rockfall-caused tree injuries in a Turkish fir stand: a case study from Kastamonu-Turkey. J Mt Sci Engl 9:137-146

Bates DM, Maechler M, Bolker B, Walker S (2015) Fitting linear mixed-effects models using lme4. J Stat Softw 67:1-48. https ://doi.org/10.18637/jss.v067.i01

Berger F, Dorren L, Kleemayr K, Maier B, Planinsek S, Bigot C, Bourrier F, Jancke O, Toe D, Cerbu G (2013) Eco-engineering and protection forests against rockfalls and snow avalanches. In: Cerbu G, Cerbu GA, Hanewinkel M, Gerosa G, Jandl R (eds) Management strategies to adapt alpine space forests to climate change risks. IntechOpen, London

Bugmann H (1996) A simplified forest model to study species composition along climate gradients. Ecology 77:2055-2074 
Da Ronch F, Caudullo G, Tinner W, de Rigo D (2016) Larix decidua and other larches in Europe: distribution, habitat, usage and threats. In: San-Miguel-Avanz J, de Rigo D, Caudullo G, Housten Durrant T, Mauri A (eds) European atlas of forest tree species. Publication Office of the European Union, Luxembourg, pp 108-110

Dormann CF, Schymanski SJ, Cabral J, Chuine I, Graham C, Harig F, Kearney M, Morin X, Römermann C, Schröder B, Singer A (2012) Correlation and process in species distribution models: bridging a dichotomy. J Biogr 39(12):2119-2131

Dorren L (2016) Rockyfor3D (v5.2) revealed-Transparent description of the complete 3D rockfall mode. eocrisQ (www.ecori sq.org).

Dorren L, Berger F (2006) Stem breakage of trees and energy dissipation during rockfall impacts. Tree Physiol 26:63-71

Dorren L, Berger F, Imeson AC, Maier B, Rey F (2004) Integrity, stability and management of protection forests in the European Alps. Forest Ecol Manag 195:165-176

Dorren L, Berger F, le Hir C, Mermin E, Tardif P (2005) Mechanisms, effects and management implications of rockfall in forests. Forest Ecol Manag 215:183-195

Dupire S, Bourrier F, Monnet JM, Bigot S, Borgniet L, Berger F, Curt T (2016) Novel quantitative indicators to characterize the protective effect of mountain forests against rockfall. Ecol Indic 67:98-107

Dussauge-Peisser C, Helmstetter A, Grasso JR, Hantz D, Desvarreux P, Meannin M, Giraud A (2002) Probabilistic approach to rock fall hazard assessment: potential of historical data analysis. Nat Hazards Earth Syst Sci 2:15-26

Farquet R, Métral R (2004) Les forêts du Mont Chemin - un héritage en évolution. Patrimoines de Martigny, 14. Bulletin.

Hantz D, Vengeon JM, Dussauge-Peisser C (2003) An historical, geomechanical and probabilistic approach to rock-fall hazard assessment. Nat Hazards Earth Syst Sci 3:693-701

Hantz D, Dewez T, Lévy C, Guerin A, Jaboyedoff M (2016) Rockfal frequency in different geomorphological conditions. In: International Symposium Rock Slope Stability 2016, Nov 2016, Lyon, France.

Kuznetsova A, Brockhoff PB, Christensen RHB (2017) lmerTest Package: Tests in linear mixed effects models. J Stat Softw 82:1-26. https://doi.org/10.18637/jss.v082.i13

Leitgeb E, Reiter R, Englisch M, Lüscher P, Schad P, Feger KH (2013) Waldböden. Ein Bidlatlas der wichtigsten Bodentypen aus Österreich, Deutschland und der Schweiz. John Wiley \& Sons, Weinheim

Lischke H, Zimmermann NE, Bolliger J, Rickebusch S, Löffler TJ (2006) TreeMig: a forest-landscape model for simulating spatiotemporal patterns from stand to landscape scale. Ecol Model 199(4):409-420. https://doi.org/10.1016/j.ecolmodel.2005.11.046

Losey S, Wehrli A (2013) Forêt protectrice en Suisse. Du projet SilvaProtect-CH à la forêt protectrice harmonisée. Bern, Swiss Federal Office of Environment, p 29

Maringer J, Ascoli D, Dorren L, Bebi P, Conedera M (2016) Temporal trends in the protective capacity of burnt beech forests (Fagus sylvatica L.) against rockfall. Eur J Forest Res 135:657-673

Moos C, Dorren L, Stoffel M (2017) Quantifying the effect of forests on frequency and intensity of rockfalls. Nat Hazard Earth Sys $17: 291-304$
Moos C, Fehlmann M, Trappmann D, Stoffel M, Dorren L (2018) Integrating the mitigating effect of forests into quantitative rockfall risk analysis - two case studies in Switzerland. Int J Disaster Risk Reduct 32:55-74

Moos C, Thomas M, Pauli B, Bergkamp G, Stoffel M, Dorren L (2019a) Economic valuation of ecosystem-based rockfall risk reduction considering disturbances and comparison to structural measures. Sci Total Environ 697:134077

Moos C, Toe D, Bourrier F, Knüsel S, Stoffel M, Dorren L (2019b) Assessing the effect of invasive tree species on rockfall riskThe case of Ailanthus altissima. Ecol Eng 131:63-72. https://doi. org/10.1016/j.ecoleng.2019.03.001

Moya J, Corominas J, Pérez Arcaz J, Baeza C (2010) Tree-ring based assessment of rockfall frequency on talus slopes at Solà d'Andorra. East Pyren Geomorphol 118(3-4):393-408

Nakagawa S, Schielzeth H (2012) A general and simple method for obtaining R2 from generalized linear mixed-effects models Methods. Ecol Evol. https://doi.org/10.1111/j.2041-210x.2012.00261.x

Perret S, Baumgartner M, Kienholz H (2006) Inventory and analysis of tree injuries in a rockfall-damaged forest stand. Eur J Forest Res 125:101-110

Stahel W (2017) Statistical regression models. Seminar for statistics. ETH Zurich, Zurich

Stoffel M, Hitz OM (2008) Rockfall and snow avalanche impacts leave different anatomical signatures in tree rings of juvenile Larix decidua. Tree Physiol 28:7

Stoffel M, Schneuwly D, Bollschweiler M, Lievre I, Delaloye R, Myint M, Monbaron M (2005) Analyzing rockfall activity (1600-2002) in a protection forest - a case study using dendrogeornorphology. Geomorphology 68:224-241

Stoffel M, Wehrli A, Kuhne R, Dorren L, Perret S, Kienholz H (2006) Assessing the protective effect of mountain forests against rockfall using a 3D simulation model. Forest Ecol Manag 225:113-122

Stokes A, Salin F, Kokutse AD, Berthier S, Jeannin H, Mochan S, Dorren L, Kokutse N, Ghani MA, Fourcaud T (2005) Mechanical resistance of different tree species to rockfall in the French Alps. Plant Soil 278:107-117. https://doi.org/10.1007/s1110 4-005-3899-3

Trappmann D, Stoffel M (2013) Counting scars on tree stems to assess rockfall hazards: a low effort approach, but how reliable? Geomorphology 180-181:180-186

Toe D, Bourrier F, Olmedo I, Monnet JM, Berger F (2017) Analysis of the effect of trees on block propagation using a DEM model: implications for rockfall modelling. Landslides 14:1603-1614

Vacchiano G, Maggioni M, Perseghin G, Motta R (2015) Effect of avalanche frequency on forest ecosystem services in a spruce-fir mountain forest. Cold Reg Sci Technol 115:9-21

Vospernik S (2004) Predicting the protection of forests against rockfall for Austria. In: International Symposium Interpraevent: 10th Conress Interpraevent, 24.-27. Mai 2004, Riva del Garda, vol. 2, pp. $109-120$

Woltjer M, Rammer W, Brauner M, Seidl R, Mohren GMJ, Lexer MJ (2008) Coupling a 3D patch model and a rockfall module to assess rockfall protection in mountain forests. J Environ Manag $87: 373-388$

Publisher's Note Springer Nature remains neutral with regard to jurisdictional claims in published maps and institutional affiliations. 